introduction of cultivation in the neighbourhood of the Great Salt Lake of North America has increased the rainfall, and caused the level of the lake to rise. JOSEPII JoHn MUR'iry

\section{Antedon rosacens (Comatula rosacea)}

Trre communication from Major Fred. H. Lang in NATURE, vol. xiv. p. 527 , as to the abundant canture of Comatula rosaca in Torbay by himself and Mr. Hunt with the dredge during last month, is a valuable conuibution to the study of the question of the apyearance and disappearance of certain marine animals in certain localities respecting which we know so little. It is specially interesting to the Birmingham Natural History and Microscopical Society, and as president of the Society and reporter during the marine excursion to Teignmouth in 1873 , alluded to by Miajor Lang, I must : :y that I read it with very great surprise and pleasure. My knowledge of the locality has extended over a period of about thirteen years, and during that time I have on several occasions dredged the ground which he mentions, and never once succeeded in taking an adult specimen of the rosy feather star, much less the more interesting pedunculate form of it. I have not, however, dredged there since our marine excursion. Mr. Gosse, whose experience is very large, and who resides in the neighbourhoud, to whom I showed our mounted specimens, had never before seen the animal in that form, and there is no mention made of the adult animal in any of his descriptive works excej:t in "A Year at the Shore," where at p. I 82 he states, "We sometimes but very rarely find on this const a very lovely form of this class of animals.

Connatula rosacen, a fine specmen of which, taken by myself in a little cove near Torquay, I have delineated." This was written in I864. In the year previously, I believe, Prof. Allman dredged the same locality, and communicated to the Royal Society of Extinburgh a paper "On a pre-brachial stage in the deyelopment of Conatula," fourded on a single specimea which he took on the occasion. It is a most remarkable circumstance, therefore, that in the space of about three years the species should have hecome numerous to the extent alluded to by Major Lang, more than a hundred being taken in one haul of the dredge! The marine naturalist who year by year finds his favourite speciriens disappearing on many parts of the coast, will derive some consolation from Major Lang's communication as a set-off to disappointmerts elsewhere. I notice that Major Lang uses-as I did in 1873 - the nomenclature, Contatula yonge of Lamarcl. Will he torgive me intorming hirn of what $r$ was then ignorantthat Ir. Carpenter, revering to the previous designation of Freninville, hos adopied Antezon rosaceter-and at the same time directing his attention to the two wonderful and exhaustive monographs on the animal in the Philosophical Transactions:(1) "On the Embryogeny of Antedon rosaceus," iy Sir Wyville Thomson, at page $5 \mathrm{I} 3$, for the year 1865 , and (2) "Researches on the Structure, Physiology, and Development of Antedon rosaccus," by Dr. Carpenter, at page 671 , for the year 1866 ?

Birmingham, October 20

W. R. HugINES

\section{Caterpillars}

Is the experiment related below has never been made before, it appears to me deserving of notice in reference to instinct and evolution. The successful result of the experiment in a single case last year led me to repeat it on a somewhat larger scale this autumn. On September 25 I placed a number of the caterpillars of Paeris brassica in boxes, and fed them with cabbage till they began to spin up. As soon as they had attached themselves by the tail and spun the suspensory girdle, and therefore before the exclusion of the chrysalis, I cut the girdle and caused them to hang vertically by the tail in the manner of the Suspensi. Mo:e than half of the caterpillars bad been ichneumonized, and some accidents to the others finally reduced the number in which the experiment was fairly tried to eight. Of these, three came out successfully, the chrysalids maintaining their hold of the caterpillar-skin until they had succeeded in fastening themselve by their anal hooks to the silk to which the caterpillars were attached The other five, as might have been expected of all, fell to the ground for want of the suspensory girdle. Counting the case last year, here then are no less than four out of nine caterpillars of the Succincti, when artificially placed in the conditions of the Suspensi, adapting tremselves to circumstances so great'y changed, and whether by plasticity of instinct or reversion to ancestral habit accomplishing a very difficult operation no less successfully.

Milford, Letterkenny, October I4

\section{Electro-Capillary Phenomena}

THE electro-capillary machine of Lippmann and his cappillary electrometer, besides the capillary clectroscope of Werner Siemens and the electro-chemical relay of Wheatstone are all iitustrutions of a phenomenon resulting from application of an electric current. I am not aware that the converse phenomenon is so generally known, namely, that the motion of the mercur: in the tube produces an electric current. If we substitute a galvanometer for the battery in a Lippmann capillary wachine and move the lever by liand, the galvanometer needle is dellected. Similarly, if in any of the electro-capillary electrometers a galvanometer is substituted for the battery and the bubble caused to move by mechanical action, electrical currents are produced which deflect the galvanometer needle.

The fullowing small insurument may serve to show this action for lecture purposes :- $a a$ is a glass tube of any convenient bore, say 15 to 20 millimetres, by $300 \mathrm{~mm}$. length ; $b$ is a cork fitting tightly into the middie of the tube, and perforated in two places where are inserted-at $c$ a tube of $\frac{1}{2} \mathrm{~mm}$. bore, slightly longer than the cork is thick, and at $d$ a longer tube, extending half way into both compartments. The ends of the tube $a a$ are stopped by the corks $c e$, through which pass the platinum wires $f g$. Sufficient mercury to quarter fill each compartment is introduced into the tube $a a_{2}$ with a small quantity of diluted sulphuric acid. The apparatus being now sealed up, the wires $f$ and $g$ are connected to the terminals of a somewhat delicate galvanometer.

By inverting the tube, as is done with an hour or egg-glass, a current flows through the galvanometer so long as any mercury runs illrough the tube $c$ (the tube $d$ is an air-tube simply). Reinverting the tube gives a current in an opposite directlon, the platinum wire from that compartment from which the mercury flow's always being the zincode of the electrical system. The current decreases with the mercury in the upper chamber as it falls, being a maximum with greatest head of mercury, and falling to

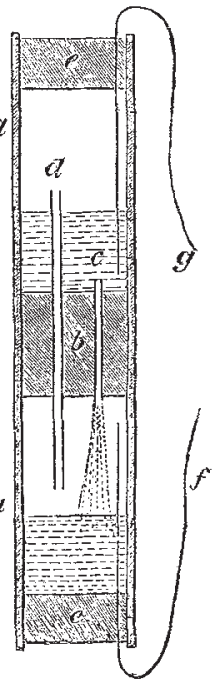
rothing when all the mercury has dropped througli. By any arrangement raintaining a constant head of mercury a constant current may be maintained.

Such an apparatus is especially uceful his an electrical laboratory where weak currents are required for the adjustment of delicate galvanometers, or where the heaing effect of currents of greater intensity and quantity are required to be avoided. The apparatus can be made in gliss and hermetically sealed. A tube like the above placed on a stand which will allow it ts revolve in a vertical plane, and fitted with a commulator, can be made to give a constant current in one direction, and is always ready to hand.

With a filter funnel the tube of which is drawn out to a fme point placed above a vessel conraining mercury and acidulated water (wires being led from the funnel and lower vessel to the galvanometer) some interesting results are to be noticed which serve to throw considerable light on the action in electro-capil lary apparatus. It will be found that when the mercury braks away from the funnel at 100 great height the mercurial column becomes discontinuous, the circuit is interrupted, and of course no current passes through the galvanometer; and when the funnel is brought so close to the lower vessel as to give only a continuous column, the current is on short circuit and the galvanometer needle undeflected. There is a point, consequentiy, between these two positions giving a maximun current in the outer circuit, and this is easily found experimentally.

\section{P. HIGGS}

\section{THE CAPERCAILZIE IN NORTHUALBERLAND}

$A$ SHORT time back an account appeared in a Newcastle paper of the occurrence of the Capercailzic at Lilburn, in the north of Northumberland. Of course it was also stated that the bird had been shot. The account was "descriptive," and the writer evidently thought he was noting a fact worth telling, for he had 